\title{
A national survey of asthma prevalence, severity, and treatment in Great Britain
}

\author{
David P Strachan, H Ross Anderson, Elizabeth S Limb, Allison O’Neill, Nicholas Wells
}

\begin{abstract}
Parents of 5472 children aged 5-17 years from 3209 families were interviewed in a nationwide household survey. In the past year, $15 \cdot 0 \%$ of children had wheezed, $2 \cdot 2 \%$ had more than 12 attacks, and $2 \cdot 3 \%$ had experienced a speech limiting attack. Altogether $4 \cdot 3 \%$ were woken more than once a week by wheezing, $13 \cdot 1 \%$ had doctor diagnosed asthma, and $13 \cdot 6 \%$ had been prescribed antiasthmatic drugs in the past year. With increasing age, morbidity related to wheezing declined to a greater extent than annual period prevalence.

The prevalence of wheeze varied little by socioeconomic group, but there were marked trends in all three indices of severity towards increased morbidity in poorer families. Diagnostic labelling and drug treatment of wheezy children did not differ substantially with socioeconomic status. Thus, a degree of socioeconomic equality exists in the process of medical care for childhood asthma in Britain. This does not appear to have resulted in equality of outcome.
\end{abstract}

(Arch Dis Child 1994; 70: 174-178)

The epidemiology of childhood asthma is of considerable interest and concern at the present time because of an increase in the use of health services ${ }^{2}$ for asthma and a possible increase in its prevalence and severity. ${ }^{3-5}$ The environmental factors responsible for causing asthma or precipitating attacks remain poorly understood and there is understandable concern that changes in lifestyle and environment may be having an adverse effect on its incidence, prognosis, or severity.

Although many epidemiological studies have been and continue to be carried out, there remain important gaps in our knowledge of the descriptive epidemiology of childhood asthma in Great Britain. One is the absence of current national prevalence figures. Another is the lack of data for the whole age range of schoolchildren; most local surveys examine one year only, or at most one section of pupils, such as primary schoolchildren. A third deficiency is the paucity of information about the severity of acute episodes, most surveys asking only about prevalence and perhaps frequency of episodes.

National cohort studies of children born in 1958 and 1970 have obtained some data about asthma or wheezing illness, and it is from these that our present knowledge about the geographical distribution and social correlates of the disease have been largely obtained..$^{6-9}$ The National Study of Health and Growth, which obtained data from a sample of 22 English primary schools after stratification for socioeconomic factors, is less useful for examining the geographical distribution of asthma. ${ }^{4}$ These existing studies, apart from being out of date, do not provide adequate information on the prevalence of severe asthma, the effect of age, or details of treatment, the main form of control of the disease.

The opportunity to address these questions arose from two independent initiatives. The first was the development of a simple 'core' questionnaire designed for large scale epidemiological studies of childhood asthma within and between countries (International Study of Asthma and Allergies in Childhood; ISAAC ${ }^{10}$ ). The second was the commissioning by Allen and Hanburys of a national survey to assess the impact of wheezing illness on children. The resulting study, reported in this paper, describes the prevalence and severity of wheezing illness and asthma in a national sample of children aged 5-17 years. It also considers the relations of wheezing illness to age, sex, social factors, region, and degree of urbanisation.

\section{Methods}

Questions, including those developed for ISAAC (appendix), were included in a weekly consumer 'omnibus' survey conducted in March and April 1992 by Research Services Limited, UK. Face to face interviews were sought with adult respondents selected according to a two stage stratified random location sample designed to be representative of all adults aged 15 and over in Great Britain.

In the first stage of sampling, 175 parliamentary constituencies were selected by stratified random sampling. In the second stage, one census enumeration district was selected from each constituency, so that the characteristics of the districts selected matched those of the population as a whole. ACORN (A Classification Of Residential Neighbourhoods) types $^{11}$ were used to classify districts for this purpose. Within each enumeration district, predetermined numbers of respondents in groups defined by sex, age, and working status were interviewed (quota sampling), to ensure that the final sample was representative of the population of Great Britain.

Among 12679 adults interviewed, there were 3209 who were parents or guardians of children aged 5-17 years. In these households, the ISAAC questionnaire was completed for 
Table 1 Symptom prevalence by age

\begin{tabular}{|c|c|c|c|c|c|c|c|c|c|c|c|}
\hline \multirow{3}{*}{$\begin{array}{l}\text { Age } \\
\text { (years) }\end{array}$} & \multirow{3}{*}{$\begin{array}{l}\text { Denominator } \\
\text { population }\end{array}$} & \multirow{3}{*}{$\begin{array}{l}\text { Wheeze } \\
\text { ever }\end{array}$} & \multirow{3}{*}{$\begin{array}{l}\text { Wheeze } \\
\text { past year }\end{array}$} & \multicolumn{7}{|c|}{ In the past year } & \multirow{3}{*}{$\begin{array}{l}\text { Asthma } \\
\text { diagnosed }\end{array}$} \\
\hline & & & & \multicolumn{3}{|c|}{ No of attacks } & \multirow{2}{*}{$\begin{array}{l}\text { Limits } \\
\text { speech }\end{array}$} & \multirow{2}{*}{$\begin{array}{l}\text { Woken } \\
\text { at least } \\
\text { once a week }\end{array}$} & \multirow{2}{*}{$\begin{array}{l}\text { With } \\
\text { exercise }\end{array}$} & \multirow{2}{*}{$\begin{array}{l}\text { Night } \\
\text { cough }\end{array}$} & \\
\hline & & & & $\overline{1-3}$ & $4-12$ & $>12$ & & & & & \\
\hline $\begin{array}{c}5-7 \\
8-10 \\
11-13 \\
14-17\end{array}$ & $\begin{array}{l}1573 \\
1293 \\
1251 \\
1355\end{array}$ & $\begin{array}{l}24 \cdot 4 \\
23 \cdot 4 \\
21 \cdot 7 \\
22 \cdot 3\end{array}$ & $\begin{array}{l}16 \cdot 7 \\
15 \cdot 9 \\
14 \cdot 2 \\
13 \cdot 0\end{array}$ & $\begin{array}{l}8 \cdot 2 \\
9 \cdot 4 \\
7 \cdot 2 \\
7 \cdot 2\end{array}$ & $\begin{array}{l}5 \cdot 2 \\
4 \cdot 0 \\
4 \cdot 5 \\
3 \cdot 0\end{array}$ & $\begin{array}{l}2 \cdot 5 \\
1 \cdot 8 \\
2 \cdot 2 \\
2 \cdot 2\end{array}$ & $\begin{array}{l}3 \cdot 2 \\
2 \cdot 6 \\
2 \cdot 2 \\
1 \cdot 2\end{array}$ & $\begin{array}{l}6 \cdot 1 \\
4 \cdot 0 \\
3 \cdot 7 \\
2 \cdot 9\end{array}$ & $\begin{array}{r}9.8 \\
11.3 \\
11.4 \\
9.3\end{array}$ & $\begin{array}{r}16 \cdot 4 \\
13.0 \\
11 \cdot 3 \\
8.6\end{array}$ & $\begin{array}{l}12 \cdot 8 \\
12 \cdot 6 \\
13 \cdot 6 \\
13 \cdot 5\end{array}$ \\
\hline All ages & 5472 & $23 \cdot 0$ & $15 \cdot 0$ & $8 \cdot 0$ & $4 \cdot 2$ & $2 \cdot 2$ & $2 \cdot 3$ & $4 \cdot 3$ & $10 \cdot 4$ & $12 \cdot 5$ & $13 \cdot 1$ \\
\hline
\end{tabular}

Figures shown are a percentage of the denominator - that is, based on all children in a given age group.

each child, and details of current treatment for chest problems were requested. Drugs prescribed in the past year, identified from showcards, were grouped into $\beta_{2}$ agonists, theophyllines, sodium cromoglycate, inhaled steroids, oral steroids, and other preparations.

Information collected routinely as part of the omnibus survey was used to classify each constituency according to standard region and degree of urbanisation. The socioeconomic status of each household was assessed according to several criteria: housing tenure, car ownership, telephone ownership, household income, and socioeconomic group. The socioeconomic groups were similar to, though not directly comparable with, the registrar general's social classes, being defined primarily by the occupation of the chief income earner, as follows: $A=$ higher managerial, administrative, or professional; $B=$ intermediate managerial, administrative, or professional; $\mathrm{Cl}=$ junior managerial, administrative or professional, and supervisory or clerical workers; $\mathrm{C} 2=$ skilled manual workers; $\mathrm{D}=$ semiskilled and unskilled manual workers; and $\mathrm{E}=$ casual workers, unemployed, or pensioners.

Statistical analysis was performed using the statistical analysis system (SAS). ${ }^{12}$ The FREQ procedure was used for cross tabulation and the LOGISTIC procedure for multiple logistic regression analyses.

\section{Results}

Questionnaire responses were obtained relating to 5472 children aged 5-17 years inclusive. A total of $1261(23.0 \%)$ children had a history of wheezing at any age and $822(15.0 \%)$ had wheezed in the year before the interview. Overall, $13 \cdot 1 \%$ of the study sample had been diagnosed by a doctor as having asthma at some time in the past. Asthma had been diagnosed among $686(54.4 \%)$ of the wheezy children, and $31(0.7 \%)$ of the children without a history of wheezing. A total of $68(1.6 \%)$ of the non-wheezy children had received drugs for asthma in the last year.

Table 1 gives the prevalence of wheezing at different ages. A more detailed breakdown by age is available from the authors on request. The proportion of children reported to have ever wheezed decreased with increasing age. The prevalence of wheezing in the last year was slightly greater in younger children, but the proportion of children experiencing 12 or more attacks each year was similar at all ages. Attacks severe enough to limit speech, and sleep disturbance due to wheezing and nocturnal cough were less common among older children. The proportion who had been diagnosed as having asthma varied little with age.

Table 2 shows the male:female ratio for each grade of wheezing at each age. The male predominance seen in preadolescent children had generally decreased by the later teenage years. This change in the sex ratio with increasing age was particularly marked for frequent and speech limiting attacks of wheezing. A history of diagnosed asthma was more common among boys than girls at all ages, however.

Table 3 outlines the geographical distribution of wheezing and asthma by latitude (north, centre, and south), longitude (Scotland, eastern England, western England and Wales), and degree of urbanisation (urban, mixed, rural). There was no marked regional difference within England and Wales, but indices of prevalence, severity, and diagnosis were lower in Scotland. Adjustment for minor geographical differences in age and socioeconomic status by multiple logistic regression did not materially alter these results.

The annual period prevalence of wheezing varied little with degree of urbanisation, but the frequency and severity of wheezing was lower in rural areas. These differences became less marked after adjustment for socioeconomic status, and only the urban-rural difference in frequent wheeze (more than 12

Table 2 Male:female prevalence ratios by age

\begin{tabular}{|c|c|c|c|c|c|c|c|c|c|c|}
\hline \multirow{3}{*}{$\begin{array}{l}\text { Age } \\
\text { (years) }\end{array}$} & \multirow[b]{3}{*}{$\begin{array}{l}\text { Wheeze } \\
\text { ever }\end{array}$} & \multirow{3}{*}{$\begin{array}{l}\text { Wheeze } \\
\text { past year }\end{array}$} & \multicolumn{7}{|c|}{ In the past year } & \multirow{3}{*}{$\begin{array}{l}\text { Asthma } \\
\text { diagnosed }\end{array}$} \\
\hline & & & \multicolumn{3}{|c|}{ No of attacks } & \multirow{2}{*}{$\begin{array}{l}\text { Limits } \\
\text { speech }\end{array}$} & \multirow{2}{*}{$\begin{array}{l}\text { Woken } \\
\text { at least } \\
\text { once a week }\end{array}$} & \multirow{2}{*}{$\begin{array}{l}\text { With } \\
\text { exercise }\end{array}$} & \multirow{2}{*}{$\begin{array}{l}\text { Night } \\
\text { cough }\end{array}$} & \\
\hline & & & $1-3$ & $4-12$ & $>12$ & & & & & \\
\hline $\begin{array}{c}5-7 \\
8-10 \\
11-13 \\
14-17\end{array}$ & $\begin{array}{l}1 \cdot 4 \\
1 \cdot 2 \\
1.4 \\
1 \cdot 2\end{array}$ & $\begin{array}{l}1 \cdot 4 \\
1 \cdot 2 \\
1 \cdot 7 \\
1 \cdot 1\end{array}$ & $\begin{array}{l}1 \cdot 5 \\
1 \cdot 3 \\
2 \cdot 5 \\
1 \cdot 2\end{array}$ & $\begin{array}{l}1 \cdot 1 \\
0.8 \\
1 \cdot 3 \\
1 \cdot 1\end{array}$ & $\begin{array}{l}2 \cdot 0 \\
1 \cdot 7 \\
0 \cdot 8 \\
1 \cdot 1\end{array}$ & $\begin{array}{l}3.0 \\
1.5 \\
1.2 \\
0.9\end{array}$ & $\begin{array}{l}1 \cdot 3 \\
0 \cdot 7 \\
1 \cdot 7 \\
0 \cdot 8\end{array}$ & $\begin{array}{l}1.9 \\
1.3 \\
1.8 \\
1.4\end{array}$ & $\begin{array}{l}1.5 \\
1.1 \\
1.5 \\
1.2\end{array}$ & $\begin{array}{l}1.8 \\
1.6 \\
1.7 \\
1.4\end{array}$ \\
\hline All ages & $1 \cdot 3$ & $1 \cdot 3$ & 1.5 & $1 \cdot 1$ & $1 \cdot 3$ & $1 \cdot 6$ & $1 \cdot 1$ & $1 \cdot 6$ & $1 \cdot 3$ & $1 \cdot 6$ \\
\hline
\end{tabular}

Figures shown are the male:female ratio in each age group. 
Table 3 Symptom prevalence by geographical region and degree of urbanisation

\begin{tabular}{|c|c|c|c|c|c|c|c|c|c|c|c|}
\hline \multirow[b]{3}{*}{ Area ${ }^{\star}$} & \multirow{3}{*}{$\begin{array}{l}\text { Denominator } \\
\text { population }\end{array}$} & \multirow{3}{*}{$\begin{array}{l}\text { Wheeze } \\
\text { ever }\end{array}$} & \multirow{3}{*}{$\begin{array}{l}\text { Wheeze } \\
\text { past year }\end{array}$} & \multicolumn{7}{|c|}{ In the past year } & \multirow{3}{*}{$\begin{array}{l}\text { Asthma } \\
\text { diagnosed }\end{array}$} \\
\hline & & & & \multicolumn{3}{|c|}{ No of attacks } & \multirow{2}{*}{$\begin{array}{l}\text { Limits } \\
\text { speech }\end{array}$} & \multirow{2}{*}{$\begin{array}{l}\text { Woken } \\
\text { at least } \\
\text { once a week }\end{array}$} & \multirow{2}{*}{$\begin{array}{l}\text { With } \\
\text { exercise }\end{array}$} & \multirow{2}{*}{$\begin{array}{l}\text { Night } \\
\text { cough }\end{array}$} & \\
\hline & & & & $1-3$ & $4-12$ & $>12$ & & & & & \\
\hline $\begin{array}{l}\text { North } \\
\text { Centre } \\
\text { South }\end{array}$ & $\begin{array}{l}2067 \\
1103 \\
2302\end{array}$ & $\begin{array}{l}22 \cdot 5 \\
26 \cdot 0 \\
22 \cdot 1\end{array}$ & $\begin{array}{l}14 \cdot 3 \\
17 \cdot 2 \\
14 \cdot 6\end{array}$ & $\begin{array}{l}7 \cdot 3 \\
7 \cdot 2 \\
7 \cdot 9\end{array}$ & $\begin{array}{l}4 \cdot 3 \\
4 \cdot 5 \\
4 \cdot 0\end{array}$ & $\begin{array}{l}2 \cdot 2 \\
2 \cdot 4 \\
2 \cdot 1\end{array}$ & $\begin{array}{l}2 \cdot 1 \\
3 \cdot 0 \\
2 \cdot 2\end{array}$ & $\begin{array}{l}4 \cdot 5 \\
4 \cdot 6 \\
3 \cdot 8\end{array}$ & $\begin{array}{r}10 \cdot 0 \\
12 \cdot 1 \\
9 \cdot 9\end{array}$ & $\begin{array}{l}12 \cdot 4 \\
13 \cdot 0 \\
12 \cdot 3\end{array}$ & $\begin{array}{l}12 \cdot 9 \\
14 \cdot 2 \\
12 \cdot 8\end{array}$ \\
\hline $\begin{array}{l}\text { Scotland } \\
\text { East } \\
\text { West }\end{array}$ & $\begin{array}{r}497 \\
3036 \\
1939\end{array}$ & $\begin{array}{l}20 \cdot 1 \\
23 \cdot 2 \\
23 \cdot 6\end{array}$ & $\begin{array}{l}12 \cdot 3 \\
15 \cdot 0 \\
15 \cdot 7\end{array}$ & $\begin{array}{l}7 \cdot 0 \\
7 \cdot 9 \\
8 \cdot 4\end{array}$ & $\begin{array}{l}3 \cdot 6 \\
4 \cdot 2 \\
4 \cdot 4\end{array}$ & $\begin{array}{l}1 \cdot 2 \\
2 \cdot 3 \\
2 \cdot 3\end{array}$ & $\begin{array}{l}0 \cdot 8 \\
2 \cdot 2 \\
3 \cdot 0\end{array}$ & $\begin{array}{l}4 \cdot 2 \\
4 \cdot 0 \\
4 \cdot 6\end{array}$ & $\begin{array}{r}9.1 \\
9.9 \\
11.5\end{array}$ & $\begin{array}{l}11.5 \\
12 \cdot 4 \\
12.9\end{array}$ & $\begin{array}{r}8 \cdot 9 \\
13 \cdot 4 \\
13 \cdot 7\end{array}$ \\
\hline $\begin{array}{l}\text { Urban } \\
\text { Mixed } \\
\text { Rural }\end{array}$ & $\begin{array}{r}3457 \\
1060 \\
932\end{array}$ & $\begin{array}{l}23 \cdot 7 \\
21 \cdot 8 \\
22 \cdot 2\end{array}$ & $\begin{array}{l}15 \cdot 3 \\
15 \cdot 0 \\
14 \cdot 1\end{array}$ & $\begin{array}{l}8 \cdot 0 \\
8 \cdot 0 \\
7 \cdot 8\end{array}$ & $\begin{array}{l}4 \cdot 2 \\
4 \cdot 2 \\
4 \cdot 4\end{array}$ & $\begin{array}{l}2 \cdot 4 \\
2 \cdot 4 \\
1 \cdot 2\end{array}$ & $\begin{array}{l}2 \cdot 5 \\
2 \cdot 5 \\
1 \cdot 8\end{array}$ & $\begin{array}{l}4 \cdot 7 \\
4 \cdot 0 \\
3 \cdot 0\end{array}$ & $\begin{array}{r}10 \cdot 5 \\
9 \cdot 2 \\
11 \cdot 4\end{array}$ & $\begin{array}{l}13 \cdot 2 \\
10 \cdot 7 \\
11.9\end{array}$ & $\begin{array}{l}13 \cdot 2 \\
12 \cdot 7 \\
12 \cdot 9\end{array}$ \\
\hline
\end{tabular}

Figures shown are a percentage of the denominator - that is, based on all children in a given geographical region or area. ^North includes Scotland, North, North West and Yorkshire and Humberside; centre includes West Midlands, East Midlands, and Wales; south includes East Anglia, South West, South East, and Greater London; east includes North, Yorkshire and Humberside, East Midlands, East Anglia, South East, and Greater London; and west includes North West, Wales, West Midlands, and South West.

Table 4 Symptom prevalence by socieconomic group

\begin{tabular}{|c|c|c|c|c|c|c|c|c|c|c|c|}
\hline \multirow[b]{3}{*}{$\begin{array}{l}\text { Socioeconomic } \\
\text { group }\end{array}$} & \multirow[b]{3}{*}{$\begin{array}{l}\text { Denominator } \\
\text { population }\end{array}$} & \multirow[b]{3}{*}{$\begin{array}{l}\text { Wheeze } \\
\text { ever }\end{array}$} & \multirow[b]{3}{*}{$\begin{array}{l}\text { Wheeze } \\
\text { past year }\end{array}$} & \multicolumn{7}{|c|}{ In the past year } & \multirow{3}{*}{$\begin{array}{l}\text { Asthma } \\
\text { diagnosed }\end{array}$} \\
\hline & & & & \multicolumn{3}{|c|}{ No of attacks } & \multirow[b]{2}{*}{$\begin{array}{l}\text { Limits } \\
\text { speech }\end{array}$} & \multirow{2}{*}{$\begin{array}{l}\text { Woken } \\
\text { at least } \\
\text { once a week }\end{array}$} & \multirow[b]{2}{*}{$\begin{array}{l}\text { With } \\
\text { exercise }\end{array}$} & \multirow[b]{2}{*}{$\begin{array}{l}\text { Night } \\
\text { cough }\end{array}$} & \\
\hline & & & & $1-3$ & $4-12$ & $>12$ & & & & & \\
\hline $\begin{array}{l}\mathrm{A} \\
\mathrm{B} \\
\mathrm{C} 1 \\
\mathrm{C} 2 \\
\mathrm{D} \\
\mathrm{E}\end{array}$ & $\begin{array}{r}131 \\
827 \\
1290 \\
1461 \\
932 \\
831\end{array}$ & $\begin{array}{l}22 \cdot 1 \\
20 \cdot 1 \\
24 \cdot 6 \\
22 \cdot 3 \\
21 \cdot 7 \\
26 \cdot 7\end{array}$ & $\begin{array}{l}14.5 \\
11.4 \\
15 \cdot 8 \\
15 \cdot 1 \\
13.5 \\
19 \cdot 1\end{array}$ & $\begin{array}{r}11.5 \\
6.8 \\
8.5 \\
7 \cdot 7 \\
6.6 \\
10.0\end{array}$ & $\begin{array}{l}1 \cdot 5 \\
3 \cdot 1 \\
4 \cdot 2 \\
4 \cdot 3 \\
4 \cdot 2 \\
5 \cdot 7\end{array}$ & $\begin{array}{l}0 \cdot 8 \\
1 \cdot 0 \\
2 \cdot 6 \\
2 \cdot 2 \\
2 \cdot 3 \\
3 \cdot 0\end{array}$ & $\begin{array}{l}0 \cdot 8 \\
1 \cdot 1 \\
2 \cdot 4 \\
2 \cdot 5 \\
2 \cdot 0 \\
3 \cdot 7\end{array}$ & $\begin{array}{l}2 \cdot 3 \\
1 \cdot 3 \\
4 \cdot 0 \\
4 \cdot 5 \\
3 \cdot 4 \\
8 \cdot 4\end{array}$ & $\begin{array}{r}9 \cdot 2 \\
6 \cdot 9 \\
11 \cdot 6 \\
10 \cdot 3 \\
9 \cdot 7 \\
13 \cdot 1\end{array}$ & $\begin{array}{r}8 \cdot 4 \\
8 \cdot 8 \\
11 \cdot 6 \\
12 \cdot 7 \\
12 \cdot 1 \\
18 \cdot 3\end{array}$ & $\begin{array}{l}13.0 \\
10 \cdot 2 \\
13.7 \\
12.5 \\
14.3 \\
14.8\end{array}$ \\
\hline \multicolumn{3}{|c|}{$\chi^{2}$ Test for trend } & $\star \star$ & & & $\star$ & $\star \star$ & $\star \star \star$ & . & $\star \star \star$ & \\
\hline
\end{tabular}

Figures shown are a percentage of the denominator - that is, based on all children in a given socioeconomic group. $\mathrm{p}^{\star}<0.05 ;{ }^{\star \star} \mathrm{p}<0.01 ;{ }^{\star \star \star} \mathrm{p}<0.001$.

attacks in the year) was statistically significant at the $5 \%$ level after controlling for age and socioeconomic group.

Table 4 shows the distribution of wheezing and asthma by socioeconomic group. Although the cumulative lifetime prevalence of wheezing varied little with socioeconomic status, there were marked trends in the prevalence of frequent and severe attacks and nocturnal symptoms. In each instance children from less privileged families were more likely to be reported as having symptoms, with particularly high levels of morbidity in the least privileged group $\mathrm{E}$. The proportion of children with a diagnosis of asthma did not vary substantially with socioeconomic status, but the trend was, if anything, towards more diagnosed asthma in the less privileged classes. These patterns were almost unaltered by adjustment for age, region, and degree of urbanisation.

A number of alternative socioeconomic indicators were analysed in relation to the prevalence and severity of wheezing: parental education, housing tenure, car and telephone ownership, household income, and ACORN

Table 5 Prescribed treatment for wheezing in past year by socioeconomic group

\begin{tabular}{|c|c|c|c|c|c|c|c|}
\hline $\begin{array}{l}\text { Socioeconomic } \\
\text { group }\end{array}$ & $\begin{array}{l}\text { Denominator } \\
\text { population }\end{array}$ & $\begin{array}{l}\text { No prescribed } \\
\text { treatment in } \\
\text { past year }\end{array}$ & $\begin{array}{l}\beta \text { agonist } \\
\text { only }\end{array}$ & $\begin{array}{l}\text { Sodium } \\
\text { cromoglycate } \\
\text { without } \\
\text { steroids }\end{array}$ & $\begin{array}{l}\text { Inhaled } \\
\text { steroids }\end{array}$ & $\begin{array}{l}\text { Other } \\
\text { drugs }\end{array}$ & $\begin{array}{l}\text { Form of } \\
\text { treatment } \\
\text { unknown }\end{array}$ \\
\hline $\begin{array}{l}A+B \\
C 1 \\
C 2 \\
D+E\end{array}$ & $\begin{array}{l}195 \\
317 \\
325 \\
329\end{array}$ & $\begin{array}{l}48 \cdot 2 \\
41 \cdot 3 \\
41 \cdot 2 \\
40 \cdot 3\end{array}$ & $\begin{array}{l}25 \cdot 1 \\
21 \cdot 1 \\
25 \cdot 2 \\
13 \cdot 1\end{array}$ & $\begin{array}{l}4 \cdot 1 \\
7 \cdot 3 \\
4 \cdot 6 \\
5 \cdot 4\end{array}$ & $\begin{array}{r}8 \cdot 2 \\
17 \cdot 7 \\
15 \cdot 1 \\
15 \cdot 3\end{array}$ & $\begin{array}{l}8 \cdot 2 \\
6 \cdot 9 \\
5 \cdot 8 \\
9 \cdot 7\end{array}$ & $\begin{array}{l}6 \cdot 2 \\
5 \cdot 7 \\
8 \cdot 0 \\
7 \cdot 8\end{array}$ \\
\hline Total & 1261 & $42 \cdot 0$ & $22 \cdot 9$ & 5.5 & $14 \cdot 8$ & $7 \cdot 8$ & $7 \cdot 1$ \\
\hline
\end{tabular}

The denominator population is children who have ever wheezed.

Ten children overall had been prescribed oral steroids in the past year; 15 children receiving inhaled steroids also received sodium cromoglycate. classification. None showed markedly stronger relations with wheezing than did socioeconomic group. Relations with parental education, housing tenure, car ownership, and household income were in a similar direction to those shown for socioeconomic group. The prevalence and severity of wheezing varied little with telephone ownership.

Table 5 shows the pattern of treatment for children in each socioeconomic group with a history of asthma or wheezing at any age. The proportion of such children receiving any prescribed treatment for asthma or wheezing in the past 12 months was similar in all groups. Children in groups A and B were less likely to be prescribed preventive treatment (cromoglycate or inhaled steroids) and were more likely to have taken inhaled $\beta_{2}$ agonists only. The types of drug prescribed did not differ greatly among the other socioeconomic groups.

\section{Discussion}

The results of this survey provide an up to date description of the scale and distribution of wheezing illness in Britain with an indication of the levels of diagnosis and drug treatment. The 12 month period prevalence of wheezing was $15 \%$. Approximately one in six of the wheezy children were reported to be having acute severe or frequent attacks, and about one quarter had frequent sleep disturbance. It is clearly a major public health problem.

This is the first national survey to describe prevalence in all school age groups. The widespread impression that asthma is more common in younger children was confirmed, but the decrease with age was more marked for 
indicators of severity than for the prevalence or frequency of wheezing itself. At younger ages boys were more affected than girls, but by the mid teens the burden was shared almost equally.

Paradoxically the proportion of children reported to have wheezed at some time in the past decreased with increasing age. The most likely reason for this is incomplete recall of past episodes, as has been documented in the 1958 birth cohort study. ${ }^{8}$ It is possible, however, that more recent generations of children have experienced more wheezing (a cohort effect). In this respect it is reassuring to find that the 12 month prevalence of wheezing was somewhere between estimates obtained in local studies carried out over the last five years, ${ }^{35}$ 13-15 which argues against an increasing propensity to wheeze in recent generations.

The geographical distribution was not unlike that described in the 1958 and 1970 national cohort studies. ${ }^{7}$ The common finding of all three studies was a low prevalence in Scotland. Similar variation was seen for dimensions of severity and frequency in this survey, though based on relatively small numbers of Scottish children. It was not explained by socioeconomic group, age, or urban-rural characteristics. The relative lack of variation elsewhere in England and Wales suggests that the environmental factors responsible for childhood asthma are widespread throughout Britain. In particular it implies that macroenvironmental factors such as climate and air pollution, though possibly important in causing variations over short periods of time, are not important determinants of regional patterns of prevalence or severity.

This study found that the 12 month prevalence of wheeze was similar in all three categories of environment (urban, mixed urban and rural, and rural), but that frequent attacks tended to be about half as common in rural areas as in mixed or urban areas, this difference persisting after adjustment for socioeconomic group and age. One factor associated with urban living which could exacerbate existing asthma is particulate and nitrogen dioxide air pollution from motor vehicle emissions. ${ }^{16}$ Another pollutant currently causing concern is ozone but as this tends to be higher in rural areas of the south, ${ }^{17}$ our findings give no support for this agent being responsible for either the urban-rural or regional variations observed.

Social factors may be important through their association with causal factors or differences in the quality or amount of medical care. The effects of socioeconomic group, age at end of parental education, tenure, car ownership, and household income were all broadly similar. With falling social status there was a modest increase in the 12 month period prevalence of wheezing (a range of about 1.3). More important was a marked trend towards more severe, more frequent, and more sleep disturbing episodes in lower socioeconomic groups (up to a threefold variation). This suggests that social factors may affect the severity of the condition more than the prevalence of wheezing per se. Alternatively, there may be differences in parental perception or reporting of asthmatic symptoms in different socioeconomic groups.

Greater severity of asthma in less privileged social classes has been observed to a varying extent in previous surveys. ${ }^{9} 18-20$ One explanation for these effects could be the existence of adverse environmental factors, such as tobacco smoke, which tend to follow the same social distribution, and in one study from the USA, this seemed to be confirmed. ${ }^{21}$ Other possible but less likely factors include poor housing. ${ }^{22}$ The other main explanation could lie in differences in medical care. Here, our results are reassuring because there was no systematic trend by socioeconomic status in the acquisition of an asthma diagnosis, nor in the prescription of drug treatment. Indeed, socioeconomic group $\mathrm{E}$, which reported the highest morbidity, had the highest rate of prescribed treatment and preventive treatments were more commonly prescribed to wheezy children from the less privileged classes. We plan a more detailed analysis of the relations between treatment and morbidity in this data set to clarify this question.

Lastly, this survey shows the scale of drug treatment for childhood asthma in present day Britain. Nearly $14 \%$ of school age children had been prescribed one or more drugs for asthma in the past 12 months. There was little regional or urban-rural variation in prescribed treatment and no trend with socioeconomic group. Equally striking was the high prevalence of a diagnosis of asthma (13\%). This is much higher than most local surveys in recent years (the highest level being reported ${ }^{5}$ from Aberdeen: $10 \cdot 2 \%$ ) and showed little association with age, region, urban-rural environment or socioeconomic group.

A descriptive analysis such as this does not address the adequacy of diagnosis and treatment, nor can it investigate important dimensions of the medical care process such as patient compliance and appropriate consultation behaviour during acute attacks. Nevertheless, our findings suggest that recent efforts to promote the use of asthma as a diagnostic label and to encourage the prescription of appropriate drugs for the treatment of wheezing have met with some success nationwide and across different socioeconomic groups. This survey would be a suitable baseline for monitoring future trends in the prevalence, severity, and medical care of asthma among children in Great Britain.

\section{Appendix}

Wording of the questions used in the interview survey (ISAAC core questions for asthma are marked with an asterisk).

* 1 Has this child ever had wheezing or whistling in the chest at any time in the past? (If no, skip to question 7)

$\star 2$ Has this child had wheezing or whistling in the chest in the last 12 months? (If no, skip to question 7) 
*3 How many attacks of wheezing has this child had in the last 12 months? (read out: $1-3,4-12$, more than 12 )

4 When this child has an attack of wheezing, how long does it usually last? (do not prompt)

*5 In the last 12 months, how often, on average, has this child's sleep been disturbed due to wheezing? (read out: never, less than one night per week, one or more nights per week)

* 6 In the last 12 months, has the wheezing ever been severe enough to limit this child's speech to only one or two words at a time between breaths?

*7 Has this child ever had asthma?

8 Has this child ever been diagnosed by a doctor as having asthma?

*9 In the last 12 months, has this child's chest sounded wheezy during or after exercise?

* 10 In the last 12 months, has this child had a dry cough at night, apart from a cough associated with a cold or chest infection?

11 Has this child taken any prescribed medications for his or her asthma or wheezing in the last 12 months? (Respondents were then prompted for the names of all drugs for asthma or wheezing by showcards).

1 Fleming DM, Crombie DL. Prevalence of asthma and hay fever in England and Wales. BMF 1987; 294: 279-83.

2 Alderson MR. Trends in morbidity and mortality from asthma. Population Trends 1987; 49: 18-23.

3 Burr ML, Butland BK, King S, Vaughan-Williams E Changes in asthma prevalence: two surveys 15 years apart. Arch Dis Child 1989; 64: 1452-6.

4 Burney PG, Chinn S, Rona RJ. Has the prevalence of asthma increased in children? Evidence from the national study of health and growth 1973-86. BMF 1990; 300: 1306-10.

5 Ninan TK, Russell G. Respiratory symptoms and atopy in Aberdeen schoolchildren: evidence from two surveys 25 years apart. BMF 1992; 304: 873-5.

6 Golding J, Butler N. Wheezing and asthma. In: Butler NJ, Golding J, eds. From birth to five: a study of the health and behaviour of Britain's 5-year-olds. Oxford: Pergammon behaviour of Britain's

7 Strachan DP, Golding J, Anderson HR. Regional variations in wheezing illness in British children: effect of migration during early childhood. $f$ Epidemiol Community Health 1990; 44: 231-6.

8 Anderson HR, Bland JM, Patel S, Peckham C. The natural history of asthma in childhood. I Epidemiol Community Health 1986; 40: 121-9.

9 Peckham C, Butler N. A national study of asthma in childhood. F Epidemiol Community Health 1978; 32: 79-85.

10 Keil U, Weiland S. International asthma and allergy study. Lancet 1992; 340: 46 .

11 Morgan M, Chinn S. ACORN group, social class and child health. $\mathcal{F}$ Epidemiol Community Health 1983; 37: 196-203.

12 SAS Institute Inc. SAS/STAT User's Guide, version 6. 4th Ed. Vols 1 and 2. Cary, NC: SAS Institute Inc, 1990.

13 Clifford RD, Radford M, Howell JB, Holgate ST Prevalence of respiratory symptoms among 7 and 11 year old schoolchildren and association with asthma. Arch Dis Child 1989; 64: 1118-25.

14 Hill RA, Standen PJ, Tattersfield AE. Asthma, wheezing and school absence in primary schools. Arch Dis Child 1989; 64: 246-51.

15 Strachan DP, Anderson HR. Trends in hospital admission rates for asthma in children. BMF 1992; 304: 873-5.

16 Quality of Urban Air Review Group. Urban air quality in the United Kingdom. First report. Bradford: Department of th Environment, 1993.

17 Department of Health Advisory Group on the Medical Aspects of Air Pollution Episodes. Ozone. London HMSO, 1991.

18 Anderson HR, Bailey PA, Cooper JS, Palmer JC, West S. Morbidity and school absence caused by asthma and wheezing illness. Arch Dis Child 1983; 83: 777-84.

19 Dawson B, Horobin G, Illsley R, Mitchell R. A survey of childhood asthma in Aberdeen. Lancet 1969; i: 827-30.

20 Littlejohns P, Macdonald LD. The relationship between severe asthma and social class. Respir Med 1993; 87: 139-43.

21 Weitzman M, Gortmaker S, Sobol A. Racial, social, and environmental risks for childhood asthma. Am $\mathcal{F}$ Dis Child 1990; 144: 1189-94

22 Strachan DP. Damp housing, mould allergy and childhood asthma. Proceedings of the Royal College of Physician Edinburgh 1991; 21: 140-6. 